\title{
RECOMMENDED NATIONAL NUCLEAR DISASTER MANAGEMENT PLAN FOR BANGLADESH
}

\author{
Labibuzzaman Mustabeen ${ }^{1}$, Md. Iqbal Hosan ${ }^{1}$, Satyajit Ghose ${ }^{2}$, Md. Jafor Dewan ${ }^{1}$ \\ ${ }^{1}$ Department of Nuclear Engineering, University of Dhaka, Bangladesh \\ ${ }^{2}$ Nuclear Safety and Security Division, Bangladesh Atomic Energy Regulatory Authority, Bangladesh
}

\begin{abstract}
Nuclear, a sophisticated, reliable and environment friendly source of energy encumbered and convulses people trust after two devastating accident (Chernobyl, Ukraine\& Fukushima, Japan) in 1986 and 2011 respectively. However to make the nuclear journey more trustworthy each country developed their own national nuclear disaster management plan. Bangladesh has already entered into nuclear world and also planned to advance further in nuclear sector by commissioning more reactors. In this study, the nuclear disaster management plans of India, Pakistan, South Africa and Russia have analyzed and then focused on some points that should be taken into consideration in Bangladesh national nuclear disaster management plan for mitigating consequences of any unwanted and unwilling events of country's first reactor named Rooppur Nuclear Power Plant (RNPP).
\end{abstract}

Keywords: Nuclear Disaster, NPP, Nuclear Accident, Disaster management plan

\section{INTRODUCTION}

Disaster management is subject which describes the ability of capacity building to mitigate the effects of a disaster. The effectiveness of DM depends on the ability of the authorities to analyses potential threats and prepares contingency plans.[Mansoor 2011, Disaster 2011] The term nuclear disaster means any radiological emergency as a result of exposure to radioactivity arising indirectly from a fission process or arising directly from radioactive material. [National 2005] Though nuclear energy is considered as one of the safe and reliable energy source all over the world but, there are some nuclear accidents that occurred in the last few decades. Some of these accidents are termed as nuclear disaster. [Fukushima 2018]To mitigate the consequences' of these disaster many country already developed their national nuclear disaster management plan.[Tughral 2011] Bangladesh has already entered into the nuclear world by constructing of its first nuclear power reactor named Rooppur 1 in November 2017.[First 2017] In near future the Government of Bangladesh is also planning to build up more nuclear power reactor in different parts of the country. Taking into considerations of the severity of the nuclear disasters, as like other country of the world, Bangladesh should also develop a proper nuclear disaster management plan. This study gives the basic idea of disaster management and nuclear disaster management plan. Then the significance of nuclear disaster management plan and also how to arrange the fund for this were described. After that, the responsibilities of different stakeholders likes: different ministry, BAERA, BAEC, IAEA and other concern and relevant organizations were mentioned. Time frame and the some points have also recommended for the management plan. A comparative discussion on India and Pakistan's, two neighboring countries disaster management plan have also included in this paper. And, finally, some strategies to implement the nuclear disaster management plan are suggested.

\section{LITERATURE REVIEW}

2.1 India's and Pakistan's Nuclear Disaster Management Plan

India accomplished the National Disaster Management Guidelines-Management of Nuclear and Radiological Emergencies in 2009. The purpose of this guideline is to prevent nuclear and radiological emergencies which are essentially manmade in nature. There are several occurrences that natural or out of human control. To diminish those occurrences some pre-planned and established structural and non-structural measures taken by different stakeholders to reduce the risks to health, life and the environment. [National 2009] After Fukushima incident Nuclear Power Corporation of India declared that inspectors had found the structures of the Indian NPPs adequate to handle 
severe natural events like earthquakes and tsunamis. India has already made a brilliant management plan and the organizations are capable to provide resources and trained manpower to save people living close to NPPs in case of an explosion or meltdown. Indian National Disaster Management Authority accepted the plan to strengthen the existing nuclear/radiological emergency management framework by engaging all the stakeholders in a holistic approach through a series of mutually interactive, reciprocal and supplementary actions to be taken on the basis of a general thread. Pakistan's capability of handing such kind of situation was become a great distrustful after the Fukushima nuclear power plant accident occurred. Lots of queries were raised about the Karachi Nuclear Power Plant. Though several experts said that it was totally in a susceptible location, but some experts discarded. [Nayyar et al. 2011, Pevez 2011] Experts claimed that Pakistan's reactors are "designed to resist earthquakes of a very high magnitude, as much as 9 on the Richter scale."[Zahir 2011] On the other hand few expert economists suggested that Pakistan should go for more trustworthy reactor designs. [Shahid 2011] Under the guidance of IAEA safeguards and state controls, Pakistan's nuclear industry operating their nuclear plants in a satisfactory level. [Tughral 2011] Following the Fukushima accident, Pakistan Atomic Energy Commission (PAEC) has done a safety review and stated its NPPs are secure against the impact of natural disasters and this assessment was done by experts from the International Atomic Energy Agency (IAEA) and the World Association of Nuclear Operators (WANO).[PAEC 2011, Nuclear 2011, Discussion 2011] The safety and security of all nuclear facilities falls under its prevalence in accordance with the Pakistan Nuclear Regulatory Authority (PNRA) ordinance. [The Mission 2011] Pakistan is bound to maintain appropriate safety standards at all its NPPs whereas they signed the Convention on Nuclear Safety (CNS) in 1994. In the National Disaster Risk Management, the Chemical, Nuclear \& Radiological (CNR) accidents are categorized as "human induced".

\subsection{Preparing a Nuclear Disaster Management Plan}

A Nuclear Disaster Management Plan should include all the things that are helps to ensure all necessary arrangements are ready in the case of emergencies.[National 2009] A Nuclear Disaster Management Plan should include following things:
- Primary and main Responsibilities of the Operator of Nuclear Power Plant

- Primary and main Responsibilities of OffSite Officials

- Nuclear Power Plants Emergency Preparedness

- On-Site Emergencies Handling

- Off-Site Emergencies Handling

- Plant Emergency Handling

- Specialized Response Teams Raising

- Responsibilities of Civil Defense (Role of Response Teams including Instruments, Equipment and Protective Gear)

- Responsibility of the Armed Forces

- Stakeholders Training--, Periodic Exercises and Mock Drills

- Emergency Response Plans/Conduct of Exercises in a Periodic Review

- Increasing capability of Infrastructure

- Increasing capability of the Network of Emergency Response Centers

- Increasing capability of Radiation Detection/Monitoring Instruments and Protective system

- Increasing capability of Real Time Monitoring Systems

- Increasing capability of the Response Infrastructure (Including Communication, Network of Roads and Transport Systems, Shelters and Alternate Sources of Food, Water and Hygiene Facilities.

- Radiological Emergencies Preparedness

It can be categorized in following ways for make it more effective.

- Increasing capability of Radiation Monitoring and Detection Systems.

- strengthening Security Systems at Border Controls and Facilities Handling Radioactive Sources

- Readiness for 'Criticality' Accidents

- Precautionary measures for Transport Accidents

- Precautionary measures for Handling a Radiological Dispersal Device

- Precautionary measures for Medical

$\checkmark \quad$ Strategy for Medical Management

$\checkmark$ Institutional and Operational Framework

$\checkmark$ Readiness for Pre-Hospital Network of Medical Facilities and Medical Enhancing Network of Radiological Safety Officers

$\checkmark$ Enhancing Capability of Quick Reaction Medical Teams 
International Journal of Engineering Applied Sciences and Technology, 2020

Vol. 5, Issue 2, ISSN No. 2455-2143, Pages 660-669

Published Online June 2020 in IJEAST (http://www.ijeast.com)

(QRMTs)/Medical

First

Responders (MFRs)

$\checkmark \quad$ Mobile Radiological Laboratory

- Hospital Preparedness

$\checkmark$ Hospital Logistics

$\checkmark$ Facilities for Training of Medical Staff

$\checkmark$ Facilities for Psycho-Social Care and Mental Health

$\checkmark \quad$ Facilities for Extended Mortuary

- Emergency/Disaster Management for Metros and Important Cities

- Intervention and Action Levels

- Availability of Response and Emergency Readiness System Financial Provisions

- Enhancing Capability by the means of Education, Knowledge Management, Awareness Generation and Training of Stakeholders

- Education and Knowledge Management, students, administrative personnel, professional panel

- Enhancing Public Awareness

- Facilities for Training of Stakeholders, first responders, administrative Personnel

- Enhancing Participation of Electronic and Print Media

- Coordination and Corporation of Social Responsibility
- Enhancing Research and Development Initiatives and Betterment of Instruments and Equipment.

\subsection{Nuclear Disaster Management Plan Time Frame and Hierarchy}

There should have a plan of time schedule or time frame to mitigate the impact if any unwanted incidences occur. It can be formed in various manners. Here is a sample of time frame:

The time phase can be categorized in three phases.

- Early Phase that may sustain some hours to some days.

- Intermediate Phase which may continue some days to some weeks.

- Late Phase that will continue some weeks to some years. This phase is the longest phase among these threes.

As people can exposed mainly three ways inhalation external exposure, external exposure and ingestion. So we have planned to mitigate the consequences by planning in these three stages. [Here the term EVACUATE means the urgent removal of people to prevent acute exposure from a radioactive plume or highly contaminated area. And RELOCATE involves the less urgent removal of people to prevent chronic exposure resulting from contamination of the environment, food and water. [National 2005]

\begin{tabular}{|c|c|c|c|}
\hline \multirow{3}{*}{$\begin{array}{l}\text { TIME } \\
\text { PHASE }\end{array}$} & $\begin{array}{l}\text { EARLY PHASE } \\
\text { hours-days }\end{array}$ & & \\
\hline & & $\begin{array}{l}\text { INTERMEDIATE } \\
\text { days-weeks }\end{array}$ & \\
\hline & & & $\begin{array}{l}\text { LATE PHASE } \\
\text { Weeks-years }\end{array}$ \\
\hline $\begin{array}{l}\text { DOMINANT } \\
\text { RISK } \\
\end{array}$ & $\begin{array}{l}\text { Radioactive } \\
\text { Cloud } \\
\end{array}$ & $\begin{array}{l}\text { deposited } \\
\text { radioactivity }\end{array}$ & $\begin{array}{l}\text { radioactivity in } \\
\text { food and water }\end{array}$ \\
\hline $\begin{array}{l}\text { EXPOSURE } \\
\text { PATHWAY } \\
\end{array}$ & $\begin{array}{l}\text { inhalation } \\
\text { external exposure }\end{array}$ & $\begin{array}{l}\text { external } \\
\text { exposure }\end{array}$ & Ingestion \\
\hline
\end{tabular}


International Journal of Engineering Applied Sciences and Technology, 2020

Vol. 5, Issue 2, ISSN No. 2455-2143, Pages 660-669

Published Online June 2020 in IJEAST (http://www.ijeast.com)

\begin{tabular}{|c|c|c|}
\hline \multirow[b]{3}{*}{ RESPONSE } & thyroid protection & \\
\hline & Shelter & food/water control \\
\hline & evacuate* & relocate** \\
\hline \multirow[t]{5}{*}{ ACTIONS } & & Re-entry \\
\hline & & cleanup \\
\hline & access control & \\
\hline & radiological assessment & \\
\hline & mass care & \\
\hline DECISIONS & urgent & complex \\
\hline
\end{tabular}

Fig 1: A Proposed Nuclear Disaster Management Time Frame [National 2005]

\section{OBJECTIVES AND STRATEGIES OF NUCLEAR DISASTER MANAGEMENT PLAN OF BANGLADESH}

The primary objectives for Nuclear Disaster Management Plan are to prevent serious deterministic effects. All-out effort should be made to minimize the incidence of stochastic effects, likes cancer and hereditary defects.

To achieve these objectives we should maintain some principles: Any protective intervention should be justified and optimized, that it should produce the maximum net benefit. In order to comply with these objectives the threshold should be kept as ALARA level which means as low as reasonably achievable. During the early phase when there is a threat of release of radioactivity protective action levels are therefore particularly urgent. [National 2005] The general Protective Actions that may be included are
a) Identification
b) Affected Area Isolation
c) Nuclear Shelter
d) Evacuation Plan
e) Relocation
f) foodstuff \& water Control
g) Decontamination

Strategy of Bangladesh Should be

- Ensuring integrated decision making, all other activities by all the related authority.

- nuclear emergency preparedness making collaboration with state of the art international principles should be confirmed oversight at national level of institutional

- Make sure that at national and international level procedures are in place to request resources.

- Make sure of training to the entire associated member to response in emergency.

- Make sure to deal with radioactive waste arising from decontamination, preparedness are in place.

\section{RESULTS AND DISCUSSION}

\subsection{Responsibilities of Various Stakeholder and Organizations}

For successful operation of a nuclear power plant different concerned stakeholder and organization of government and also outside government grief have to perform several duties. A proper cumulative, joint hand co-operation is precursor of this. So, to make nuclear a secure and sustainable source all relevant parties should work together in a helping hand. The 
relevant authorities and their duties are described briefly.

\section{i. Government of Bangladesh}

The government of the People's Republic of Bangladesh signed the Convention on Nuclear Safety (CNS) on 21 September 1995. Consequently it was formally accepted and entered into force on 24 October 1996. The Government of Bangladesh is the protagonist for the coordination and management of any national nuclear disaster management and must deal with such a disaster in terms of existing legislation and contingency arrangements. These obligations of the National Executive will be implemented by the relevant officials.

\section{ii. Ministry of Science and Technology}

Ministry of science and technology is working for the development of new technological development to build up human resources, to create new scientific knowledge. They can play a vital role in nuclear disaster management plan. They can keep update about the new research work and can also help to build up skilled and scientific knowledgeable manpower.

\section{iii. Ministry of Power, Energy and Mineral Resources (MPEMR)}

This ministry is performing their role to fulfilling the energy demand of the people of the country and to make the best uses of natural resources of the country. In Nuclear regard it can play role to support the concern authority by giving various information including geological information and make good collaboration to fulfilling the public energy demand.

\section{iv. Finance Ministry}

One of the top most important ministries for nuclear sector actually for any sector, for any kind of plan. For implementing different kinds of plan financing is a must one. Finance ministry can keep part in the management plan by giving different recommendation and ensuring the liquidity of fund and other finance related support during the installation of nuclear industry as well as disaster management plan.

\section{v. Ministry of Home Affairs}

Though there is a very little possibility of attack the nuclear industry from domestic level but ministry of home affairs can play a role to ensure the safety from home side with adequate information and security resources likes police, ansar etc. during the various stages of installations, operation and decommissioning of nuclear power plan.

\section{vi. Ministry of foreign affairs}

Ministry of foreign affairs can keep a part in nuclear disaster management plan. It can help in importing various nuclear materials, in keeping good ties with other nations, helps in various embassy when people go for training, to ensure international terrorist security and maintaining logical relationship with various international organization.

\section{vii. Ministry of Disaster management and Relief}

The responsibility of this ministry is to ensure quick response in the case of disaster occurrence. But the response of in nuclear disaster is totally different than natural disaster response. For this it can help the concern authority with logistic support to build up a trained group and gives all kinds of facilities and access in preparedness for disaster management and during an unwanted occurrence.

\section{viii. Bangladesh Atomic Energy commission (BAEC)}

Bangladesh Atomic Energy commission (BAEC) is the mainly responsible authority under Ministry of science and Technology to take care of country's long cherished nuclear industry. Nuclear Power and Energy Division (NPED) of Bangladesh Atomic Energy Commission (BAEC) was primarily responsible for carrying out all project related activities before formal creation of the project management unit (PMU) named First-phase of Rooppur Nuclear Power Project. In December 2015, BAEC signed the main contract of the construction with JSC Atomstroyexport (ASE). [Bangladesh 2017] Construction of the first unit. BAEC should help to Establish and implement a disaster management plan and supervise all the associate organizations for successful operation of the nuclear power plant.

\section{ix. Nuclear Power Plant Company of Bangladesh (specially NPCBL)}

Nuclear Power Plant Company Bangladesh Limited (NPCBL) is the mainly responsible institution to operate Rooppur Nuclear power Plant nuclear reactor 
successfully. NPCBL and others companies if established for the operation of nuclear power plant, should have a rules and regulation for each and every sectors and stages. It should have a guides and regulation for all sectors worker including administration, operators and for others. So, the workers are bound to perform their responsibility with care. It can also, make a plan to establish a center to support the worker with Psychotherapy. NPCBL should acts as the National Competent Authority and Contact Point (24 hour Emergency Control Centre) for the following International Atomic Energy Agency Conventions:

$\checkmark$ Convention on early notification of a nuclear accident

$\checkmark$ Convention on assistance in the case of a nuclear accident or radiological emergency NPCBL must establish a formal procedure to implement these obligations. [National 2005]

\section{x. Bangladesh Atomic Energy Regulatory Authority (BAERA)}

A regulatory body, named Bangladesh Atomic Energy Regulatory Authority (BAERA), has been established in February 2013 to oversee all safety aspects and has been given appropriate authority/powers to develop safety regulations, codes $\&$ standards and has powers to inspect \& enforce safety provisions in nuclear installations and related activities. On 21 June 2016, Bangladesh Atomic Energy Regulatory Authority (BAERA) issued "Siting Licence" to Bangladesh Atomic Energy Commission. Recently a National Report has been prepared by BAERA in accordance with the "Guidelines Regarding National Reports under the Convention on Nuclear Safety" issued as information circular INFCIRC/572/Rev.4 which reflects/covers the activities associated with the research reactor as well as the latest developments in the on-going nuclear power programme in Bangladesh and indicates how it meets the obligations of each of the articles of the Convention. [Bangladesh 2017]

Bangladesh Atomic Energy Regulatory Authority (BAERA) has already made a BAERA ACT-2012, for the safe and peaceful uses of nuclear materials. It also performs the duty of giving and renew license to different institutions to use nuclear material for peaceful purposes. It can strength its inspection to nuclear facility and establish transparent and accountable environment. The regulatory body must ensure that the nuclear emergency plan, of the holder of a nuclear authorization, is effective for the protection of persons should a nuclear accident occurring. The regulator must recommend standards for the protection of the worker and the off-site public and the keeping of records of nuclear accidents.

\section{xi. Responsibility of the Nuclear Authorization Holder}

A nuclear authorization must enter into an agreement with relevant authorities to establish a nuclear emergency plan and submit such plan for approval in the case there is a possibility that a nuclear accident affecting the public may occur the holder. [National 2005]

The others responsibilities are:

- Responsible for technical and radiological assessment during all phases of the emergency

- implementing on-site protective actions

- Responsible for recommending off-site public protective actions to the relevant government authority (ies) based on formal procedures.

- in case of nuclear damage providing financial security as per regulations

It should be mentioned that the obligation of "prevention" under the Nuclear Disaster Management Act is addressed by the operator (holder of the nuclear authorization) through the implementation of the regulatory requirements under the BAERA, NPCBL act and regulation.

\section{xii. Other National Organizations \& Institutions}

In Bangladesh other National organizations and Institutions will support all the concern authority and institutions in terms of their legislation, functions.

\section{xiii. International Atomic Energy Agency (IAEA)}

The IAEA helps maintain and strengthen effective emergency preparedness and response capabilities on a national and international level. As part of these activities, it develops safety standards, guidelines and technical tools; assists Member States in building the capacity for emergency response; and maintains the IAEA Incident and Emergency System to efficiently implement its role in response to nuclear or radiological incidents and emergencies, regardless of whether they arise from accident, negligence or 
deliberate act. They have also various publications on emergency managements. Likes

- Pocket Guide for Medical Physicists Supporting Response to a Nuclear or Radiological Emergency

- Medical Management of Radiation Injuries

- International Radiological Information Exchange (IRIX) Format

- Accident Management Programmes for Nuclear Power Plants

- Arrangements for Preparedness for a Nuclear or Radiological Emergency

- Preparedness and Response for a Nuclear or Radiological Emergency etc.

As part of their work under the Action Plan, Member States introduced measures to enhance nuclear safety, including those taken in response to the results of assessments of nuclear power plants' vulnerability to extreme external events. The IAEA's work under the Action Plan included strengthening relevant safety standards and peer review services, and enhancing efforts to assist Member States in building capacity for safety. [IAEA 2011]

The IAEA will inform and provide information to any State party in terms of the international Conventions referred to in 3.10. On request from Bangladesh the IAEA will also provide assistance in case of a nuclear emergency or the IAEA may request assistance from Bangladesh in case of a nuclear emergency elsewhere.

\section{xiv. National Disaster Management Centre}

The government of Bangladesh can establish a national nuclear disaster center. It's main duty is to coordinate the functions of all ministry, responsible authority, organizations, institutions etc. The Centre is responsible to declare a National Disaster on the recommendation of the affected area. The Centre will execute its powers and duties as per the national Act. [National 2005a]. It can perform the following responsibilities:

- Install, operate and maintain the national radioactivity monitoring network.

- Provide advice on the potential consequences of a nuclear accident and on protective measures to be taken by the Government and the Emergency Response Co-ordination Committee (ERCC).

- Implement the relevant international conventions.

- Establish an Emergency Control Centre at the Institute's premises including accommodation for the Emergency Response Co-ordination Committee.

\subsection{Inspection, Review and update of the nuclear disaster management plan}

The Bangladesh nuclear disaster management plan will be reviewed on an ongoing basis and updated as required. There should have an inclusive list specifying role of all these stakeholders. Here we are proposing a hierarchy of nuclear disaster management plan. 


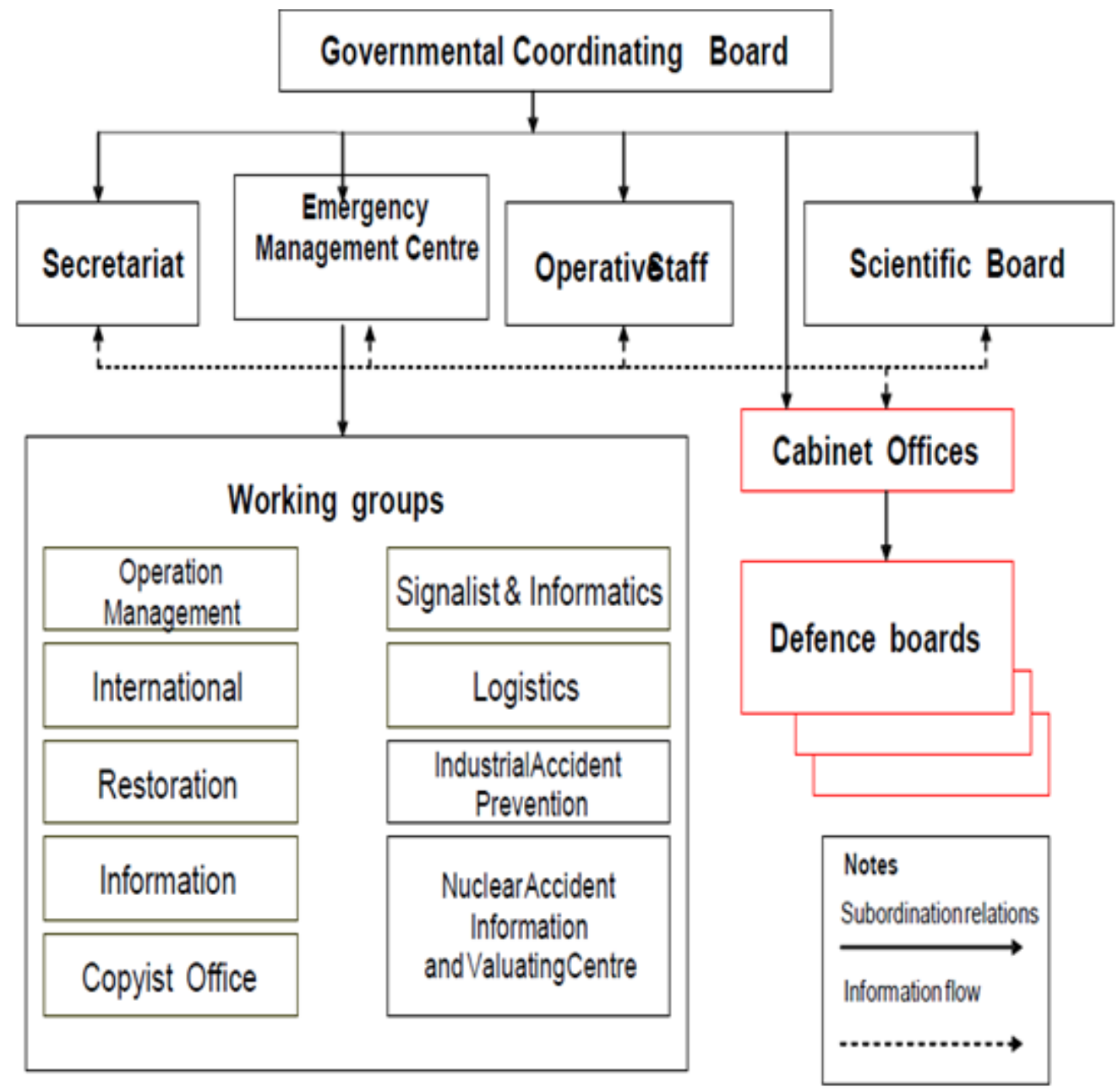

Fig 2: Proposed Nuclear Disaster Management Plan Hierarchy for Bangladesh

The concerned authority can build up this type of inclusive team for authentic inspection, review and update of the nuclear disaster management plan.

\subsection{Significance and Financing}

A Nuclear Disaster Management Plan can help to mitigate and prevent natural or man-made nuclear and radiological emergencies. Sometimes these factors beyond human control, such emergencies can be managed through certain pre-planned and established structural and non-structural measures taken by various stakeholders, as to mitigate risks to health, life and the environment.

The Plan can handle nuclear disaster management at domestic government level and including Nuclear Reactors and other Nuclear Fuel Cycle facilities, nuclear powered vessels, transport of radioactive material within the nuclear fuel cycle (air, land \& sea), radioactive fallout from nuclear weapons. [National 2005]

The financial needs of implementing the plan for training the staff, building up capable manpower, cost for their salary and for all others activities will be met from the profit of associated operation company, currently NPCBL. In the case of emergency government can support them. But obviously the lion part must be fulfilled by NPCBL.

\section{CONCLUSION}

Nuclear Disaster and Emergency plan paves the way to make nuclear industry more secured. Disaster Management is not a knee jerk reaction to a problem. It requires serious planning and is a deliberate process. It requires human resources with technical knowledge, equipment and preparations. To mitigate the consequence, we should identify the nature of hazard, prepare a detailed disaster risk assessment of 
the vulnerability of the life, property, and review the technical features of hazards and analysis of the physical, social, economic and environmental dimensions of vulnerability and exposure. After that, based on these analyses a number of response contingencies should prepared and disseminated the plans to the rescue and relief agencies and shared with the affected people. Culture of risk reduction can be developed through public awareness activities. This can be engendered through public information and education. A sustainable and cumulative system constructed by all concerned authorities including the government level is very essential. The government should have a prudent disaster management plan and astute preparation, establishment of information centers and networks and community and participatory action as Bangladesh has long term plan in nuclear journey. Nuclear research, education and building up management capabilities are inevitable and linchpin to secure our nuclear journey.

\section{ACKNOWLEDGEMENT}

The authors are very much grateful to all of the responsible authority who gives us the documents and guidance in different stages of our research.

\section{REFERENCES}

1. Mansoor Raza, (2011). Accountability in Disaster. Dawn April, 13.

2. "Disaster Management Theories," (2011) Kobenhavnas Universitet. www.ku.dk/disaster_management (accessed March 30, 2011).

3. National Nuclear Disaster Management Plan (2005), Rev 0, Approved by the DirectorGeneral 5 October.

4. "Fukushima nuclear disaster: Japan confirms first worker death from radiation" (2018). BBC News. BBC. Retrieved 5 September 2018.

5. Tughral Yamin (2011). NUCLEAR DISASTER MANAGEMENT . IPRI Journal XI, no. 2, pp80-101.

6. "First Concrete poured at the constructed Rooppur NPP site (Bangladesh)"(2017), The communication department of ROSATOM, 30 November. https://rosatom.ru/en/presscentre/news/first-concrete-poured-at-theconstructed-rooppur-npp-site-bangladesh/

7. National Disaster Management Guidelines-Management of Nuclear and Radiological Emergencies, (2009). A publication of the National Disaster
Management Authority, Government of India. ISBN 978-81-906483-7-0, February 2009, New Delhi.

8. A.H. Nayyar, M.V. Rammana \& Zia Mian,(2011) "Fukushima Lessons," Dawn, January27, 2011.

9. Pevez Hoodbhoy,(2011) "Pakistan Can't Handle Fukushima," Express Tribune, March 22. http://tribune.com.pk/story/136020/pakistancant-handle-fukushima/ (accessed March 23, 2011)

10. Zahir Kazmi, (2011) "Fact and Fiction, Letter to the Editor;" Express Tribune, March 23. http://tribune.com.pk/story/136738/fact-andfiction/ (accessed March 25 2011).

11. Shahid Javed Burki, (2011) "Will Japan's Tsunami Wave Hit Pakistani Shores?" Dawn Economic \& Business Review, April 4-10.

12. PAEC official website, www.paec.gov.pk/ (accessed March 21, 2011).

13. "Nuclear Power Plants Safe, Says Pakistan," (2011) Dawn, March 15. http://www.dawn.com/2011/03/15/nuclearpower-plants-safe-sayspakistan.html(accessed March 17, 2011).

14. Discussion with the spokesperson of the PNRA Bushra Nasim, on the sidelines of the International Seminar on Nuclear Safety and Security Challenges of the 21st Century, 2123 April 2011, National Centre of Physics, Islamabad, Pakistan

15. The mission of the PNRA is: "To ensure safe operation of nuclear facilities and to protect radiation workers, general public and the environment from the harmful effects of radiation by formulating and implementing effective regulations and building a relationship of trust with the licensees and maintain transparency in its actions and decisions," www.pnra.org/ (accessed March 17, 2011).

16. L. M. Toth, A. P. Malinauskas, G. R. Eidam, \& H. M. Burton (eds.) (1986). The Three Mile Island: Diagnosis and Prognosis, Washington: American Chemical Society, 2.

17. "Backgrounder on the Three Mile Island Accident," US NRC (2011), http://www.nrc.gov/reading-rm/doccollections/fact-sheets/3mile-isle.html (accessed March 17, 2011). 
International Journal of Engineering Applied Sciences and Technology, 2020

Vol. 5, Issue 2, ISSN No. 2455-2143, Pages 660-669

Published Online June 2020 in IJEAST (http://www.ijeast.com)

18. Bangladesh National Report to the Seventh Review Meeting of the Convention On Nuclear Safety (2017), Bangladesh.

19. IAEA Action Plan on Nuclear Safety (2011).

https://www.iaea.org/topics/nuclear-safetyaction-plan

20. National Emergency Plan for Nuclear

Accidents December (2005a),

RPII_NEPNA_Doc_05. 